\title{
MARKET Discipline WoRKIng For AND Against FinANCial STABILITY: The Two Faces of Equity CaPiTAL in U. S. CoMmercial BANKING
}

\author{
JOSEPH P. HUGHES \\ RUTGERS UNIVERSITY \\ LORETTA J. MESTER \\ FEDERAL RESERVE BANK OF CLEVELAND \\ AND ThE WHARTON SCHOOL, UNIVERSITY OF PENNSYLVANIA \\ Choon-Geol Moon \\ HANYANG UNIVERSITY \\ DECEMBER 2016
}

\begin{abstract}
The second Basel Capital Accord points to market discipline as a tool to reinforce capital standards and supervision in promoting bank safety and soundness. The Bank for International Settlements contends that market discipline imposes strong incentives on banks to operate in a safe and efficient manner - in particular, to maintain an adequate capital base to absorb potential losses from their risk exposures.

Using 2007 and 2013 data on top-tier, publicly traded U.S. bank holding companies, we find that market discipline rewards risk-taking at some of the largest U.S. financial institutions. In particular, we find evidence of two faces of equity investment - dichotomous capital strategies for maximizing value. At banks with higher-valued investment opportunities, a marginal increase in their equity capital ratio is associated with better financial performance, while at banks with lowervalued investment opportunities, a marginal decrease in their equity capital ratio is associated with better financial performance. Because the largest U.S. financial institutions tend to have lowervalued investment opportunities, our results suggest that they may have a market-based incentive to reduce their capital ratio. To the extent that market discipline rewards reducing the capital ratio among the largest banks, it would tend to undermine financial stability. Our results support the need for regulatory capital requirements.
\end{abstract}

*The views expressed in this paper do not necessarily reflect those of the Federal Reserve Bank of Cleveland or the Federal Reserve System. Hughes thanks the Whitcomb Center for Research in Financial Services at the Rutgers Business School for its support of data services used in this research.

Correspondence to Hughes at Department of Economics, Rutgers University, New Brunswick, NJ 089011248; jphughes@rci.rutgers.edu. To Mester at Federal Reserve Bank of Cleveland, Executive Office, Federal Reserve Bank of Cleveland, P.O. Box 6387, Cleveland, OH 44101-1387;

Loretta.Mester@clev.frb.org. To Moon at Department of Economics and Finance, College of Economics and Finance, Hanyang University, Seoul 133-791, Korea; mooncg@gmail.com.

JEL Codes: C58, G21, G28.

Key Words: banking, efficiency, capital structure, charter value 


\section{MARKet Discipline Working For and Against FinANCiAl STABility: The Two Faces of Equity Capital in U. S. Commercial Banking}

\section{Introduction}

The second Basel Capital Accord rests on three complementary pillars. The Bank for International Settlements describes the third pillar:1 "Pillar 3 recognises that market discipline has the potential to reinforce minimum capital standards (Pillar 1) and the supervisory review process (Pillar 2), and so promote safety and soundness in banks and financial systems. Market discipline imposes strong incentives on banks to conduct their business in a safe, sound and efficient manner, including an incentive to maintain a strong capital base as a cushion against potential future losses arising from risk exposures."

Consistent with this view, before the financial crisis, former Federal Reserve Board Chairman Alan Greenspan also placed emphasis on market discipline as a source of financial stability: "Except where market discipline is undermined by moral hazard, for example, because of federal guarantees of private debt, private regulation generally has proved far better at constraining excessive risk-taking than has government regulation." ${ }^{2}$ Later he expressed surprise that market discipline did not restrain risk-taking at the largest financial institutions: “. . . those of us who have looked to the self-interest of lending institutions to protect shareholders' equity (myself especially) are in a state of shocked disbelief."3

At least one banker has suggested that market forces do not necessarily lead to less risktaking. Charles Prince, then CEO and chairman of Citigroup, famously observed, "When the music

\footnotetext{
${ }^{1}$ See Bank for International Settlements (2001), p. 1.

${ }^{2}$ Greenspan (2005).

${ }^{3}$ Greenspan (2008).
} 
stops, in terms of liquidity, things will be complicated. But as long as the music is playing, you've got to get up and dance. We're still dancing."4

In this paper we investigate the role of market discipline in banks' risk-taking, in particular, the relationship between equity capital levels and bank financial performance. We apply the measurements and techniques developed by Hughes, Lang, Moon, and Pagano (1997) and described in Hughes, Lang, Mester, Moon, and Pagano (2003) and more recently in Hughes, Mester, and Moon (2016), to 2007 and 2013 data on top-tier, publicly traded U.S. bank holding companies. We find evidence suggesting that market discipline rewards risk-taking at some of the largest U.S. financial institutions. In particular, we find evidence of two faces of equity investment dichotomous capital strategies for maximizing value. At banks with higher-valued investment opportunities, on the margin an increase in their equity capital ratio is associated with better financial performance, while at banks with lower-valued investment opportunities, a marginal decrease in their equity capital ratio is associated with better financial performance.

Because the largest U.S. financial institutions tend to have lower-valued investment opportunities, our results suggest that they may have a market-based incentive to reduce their capital ratio. To the extent that market discipline rewards reducing the capital ratio among the largest banks, it would tend to undermine financial stability. Our results support the need for regulatory capital requirements. They are also consistent with other papers in the literature that suggest that market discipline may have actually encouraged risk-taking at large financial institutions leading up to the crisis. For example, Laeven and Levine (2009) examined the largest banks in a number of countries and concluded that large, diversified shareholders at these banks generally prefer riskier investment strategies than managers, and that they exercise sufficient corporate power to effect the riskier strategies.

\footnotetext{
4 Prince, as quoted by Nakamoto and Wighton (2007).
} 
The rest of the paper is organized as follows. Section I reviews the literature on capital strategies. Section II describes the two measures of financial performance that we use to investigate the role of equity capital in the financial performance of U.S. commercial banks. Section III presents a measure of the value of banks' investment opportunities. Section IV discusses the data. Section V presents our results, and Section VI concludes.

\section{Literature Review}

Marcus (1984) investigates the different risk-taking incentives of banks with high-valued investment opportunities versus those with low-valued opportunities. He shows that value maximization for banks with low-valued investment opportunities involves taking more risk to exploit the option value of explicit and implicit deposit insurance, while, for banks with high-valued opportunities, value maximization entails less risky investment strategies to protect their charters. Entry into banking requires a charter issued by a regulatory authority. Restrictions on bank entry create market power, which makes valuable investment opportunities even more valuable. In contrast, competitive markets tend to undermine charter value. ${ }^{5}$ In the case of banks with highvalued opportunities, to the extent that market discipline encourages managers to adopt valuemaximizing investment strategies, these strategies entail less risk-taking and so promote financial stability, while, in the case of banks with low-valued opportunities, market discipline would encourage more risk-taking and would tend to work against financial stability.

A contrasting incentive that encourages risk-taking results from mispriced deposit insurance. The general lack of risk-pricing and the implicit insurance obtained from the too-big-tofail doctrine weaken the link between the cost of borrowed funds and the riskiness of investment strategies. Thus, the cost of funds does not respond fully to more risky investment strategies with higher expected returns. For banks operating in more competitive markets and in markets with

\footnotetext{
${ }^{5}$ Keeley (1990) finds evidence that increasing competition in U.S. banking markets during the 1980s eroded charter value and led to increasing financial leverage.
} 
less valuable investment opportunities, smaller expected bankruptcy costs make more risky investment strategies that exploit the option value of deposit insurance and the too-big-to-fail doctrine value maximizing.

Using 1994 data on U.S. bank holding companies, Hughes, Lang, Moon, and Pagano (1997) find evidence of these dichotomous investment strategies. Keeley (1990) considers the period during which interstate branching regulations were liberalized, which increased competition among banks and reduced their charter values. He links the decline in charter values with increased financial leverage in U.S. banking. Grossman (1992) considers the period after the passage of deposit insurance for U.S. thrifts in 1934 and finds evidence that insured thrifts adopted more risky investment strategies than uninsured thrifts.

Calomiris and Nissim (2007) regress the ratio of the market value of equity to its book value on variables characterizing banks' investment strategies and find that the market-to-book equity ratio is negatively related to capital for banks with lower capital ratios and positively related for banks with higher capital ratios. Thus, banks with a lower capital ratio appear to be overcapitalized, while those with a higher capital ratio, undercapitalized. De Jonghe and Vander Vennet (2005) use the noise-adjusted measure of Tobin's $q$ ratio to measure performance and find a nonmonotonic relationship of market value and the book-value ratio of equity capital to assets - a relationship qualitatively the same as the one found by Calomiris and Nissim (2007).

McConnell and Servaes (1995) propose a hypothesis for nonfinancial firms that yields implications similar to Marcus (1984). Firms with high-valued investment opportunities for which the underinvestment problem is particularly acute maximize value by employing less financial leverage. On the other hand, firms with low-valued investment opportunities for which overinvestment from free cash flow reduces value maximize value by using more financial leverage 
to put performance pressure on managers. The authors refer to these dichotomous strategies as the "two faces of debt."

\section{Measuring Financial Performance ${ }^{6}$}

Unlike accounting-based measures of performance that gauge current and past performance, a firm's market value provides the market's expectation of the firm's current and future cash flows discounted at a rate that reflects the market's assessment of the firm's exposure to market-priced risk. As in Hughes, Mester, and Moon (2016), we measure banks' performance by the market value of their assets and by the difference between their best-practice market value of assets and their achieved market value, adjusted to eliminate statistical noise. While market value is correlated with agency problems, the difference between potential and realized market value lost market value - more directly gauges the extent of agency problems.

The best-practice market value of assets is obtained from the estimation of a stochastic frontier - an upper envelope of market value as a function of the book-value investment in assets for publicly traded, top-tier U.S. bank holding companies. The frontier answers the question: what is the best-practice market value of assets observed for any given book-value investment in assets? ${ }^{7}$ The elimination of statistical noise from the difference between the best-practice and observed market values means that this lost market value represents systematic underperformance. We normalize the lost market value by the best-practice value so that it is a measure of the marketvalue inefficiency ratio. As a measure of systematic underperformance, market-value inefficiency

\footnotetext{
${ }^{6}$ This section follows the original exposition of Hughes, Lang, Moon, and Pagano (1997), which is restated more recently in Hughes, Mester, and Moon (2016) and Hughes, Jagtiani, and Mester (2016).

7 This technique of measuring performance was proposed by Hughes, Lang, Moon, and Pagano (1997) and was used by Hughes, Lang, Mester, and Moon (1999) to study bank consolidation; by Hughes, Lang, Mester, Moon, and Pagano (2003) to study bank asset sales and acquisitions; and by Hughes, Mester, and Moon (2001) and Hughes and Mester (2013b) to evaluate bank scale economies measured along an expansion of bank output that maximizes the bank's value. Note, that this path is not generally equivalent to the path that minimizes the bank's cost. See Hughes and Mester (2013a, 2013b) for further discussion.
} 
captures such managerial phenomena as sub-par investment strategies, perquisite consumption, taking too little or too much risk to enhance control, nepotism, prejudicial discrimination, and subpar locational decisions. While the market value of assets normalized by the book value, a commonly used proxy for Tobin's $q$, measures achieved performance, the market-value inefficiency ratio gauges the shortfall between best-practice and achieved performance and, as such, measures the extent of agency costs.

In each of the two years, we use maximum likelihood techniques to estimate the highest potential value of a bank's investment in its assets by fitting an upper envelope of the market value of banks' assets (MVA) to their replacement cost, proxied by their book value net of goodwill $(B V A)$ :

$$
M V A_{\mathrm{i}}=\alpha+\beta\left(B V A_{\mathrm{i}}\right)+\gamma\left(B V A_{\mathrm{i}}\right)^{2}+\varepsilon_{\mathrm{i}}
$$

where $\varepsilon_{\mathrm{i}}=v_{\mathrm{i}}-\mu_{\mathrm{i}}$ is a composite error term used to distinguish statistical noise, $v_{\mathrm{i}} \sim$ iid $N\left(0, \sigma_{v}{ }^{2}\right)$, from the systematic shortfall, $\mu_{\mathrm{i}}(\geq 0)$, from bank i's highest potential (frontier) market value. We assume that $\mu_{\mathrm{i}}$ is distributed normally for the 2007 frontier, $\mu_{\mathrm{i}}(\geq 0) \sim$ iid $N\left(0, \sigma_{\mu}{ }^{2}\right)$, and, for the 2013 frontier, exponentially, $\mu_{\mathrm{i}}(>0) \sim \theta \exp (-\theta u)$. The quadratic specification allows the frontier to be nonlinear. The frontier value, $F M V A_{\mathrm{i}}$, is given by the deterministic kernel of the stochastic frontier,

$$
F M V A_{\mathrm{i}}=\alpha+\beta\left(B V A_{\mathrm{i}}\right)+\gamma\left(B V A_{\mathrm{i}}\right)^{2}
$$

The stochastic frontier, $S F M V A_{\mathrm{i}}$, consists of the deterministic kernel and the two-sided error term: $S F M V A_{\mathrm{i}}=F M V A_{\mathrm{i}}+v_{\mathrm{i}}$. Figure 1 illustrates the relationship of the deterministic kernel to observed market value at any given book-value investment in assets.

The difference between a bank's stochastic frontier market value and the observed market value defines the bank's market-value shortfall, $\mu_{\mathrm{i}}$, which is measured in dollars of lost market value. Formally, a bank's shortfall is defined either by the difference between its potential value on 
the stochastic frontier and its observed market value or, equivalently, by the difference between its value on the deterministic kernel and its noise-adjusted market value:

$$
\mu_{\mathrm{i}}=S F M V A_{\mathrm{i}}-M V A_{\mathrm{i}}=F M V A_{\mathrm{i}}-\left(M V A_{\mathrm{i}}-v_{\mathrm{i}}\right)
$$

where $M V A_{\mathrm{i}}-v_{\mathrm{i}}$ is the noise-adjusted observed market value of assets. Since the shortfall, $\mu_{\mathrm{i}}$, cannot be directly measured, it is estimated as the expectation of $\mu_{\mathrm{i}}$ conditional on $\varepsilon_{\mathrm{i}}$ :

$$
\text { shortfall }_{\mathrm{i}}=\mathrm{E}\left(\mu_{\mathrm{i}} \mid \varepsilon_{\mathrm{i}}\right)=F M V A_{\mathrm{i}}-\left(M V A_{\mathrm{i}}-\mathrm{E}\left(v_{\mathrm{i}} \mid \varepsilon_{\mathrm{i}}\right)\right)
$$

For more details on this technique, see Bauer (1990) and Jondrow, Lovell, Materov, and Schmidt (1982). The market-value inefficiency ratio expresses the shortfall as a proportion of the highest potential value:

$$
\text { market-value inefficiency } \text { ratio }_{\mathrm{i}}=\operatorname{shortfall}_{\mathrm{i}} / F M V A_{\mathrm{i}}=\mathrm{E}\left(\mu_{\mathrm{i}} \mid \varepsilon_{\mathrm{i}}\right) / F M V A_{\mathrm{i}}
$$

We can use the noise-adjusted observed market value expressed in (3) to adjust the standard proxy for Tobin's $q$ ratio,

$$
\text { Tobin's } q \text { ratio }=M V A_{\mathrm{i}} / B V A_{\mathrm{i}}
$$

for noise:

$$
\text { noise-adjusted Tobin's } \boldsymbol{q} \text { ratio }=\left(M V A_{\mathrm{i}}-v_{\mathrm{i}}\right) / B V A_{\mathrm{i}} .
$$

A number of studies have used the market-value inefficiency ratio as well as the noise-adjusted $q$ ratio to measure performance. ${ }^{8}$

Figure 1 (reproduced from Hughes, Jagtiani, and Mester, 2016) provides an illustration of the concepts. In this example, bank i invests 100 in assets and achieves a market value adjusted for statistical noise, $v_{i}$, of 108 . Its highest potential value is 120 . The shortfall of its achieved value

\footnotetext{
${ }^{8}$ See, for example, Hughes, Lang, Mester, and Moon (1999); Habib and Ljungqvist (2005); De Jonghe and Vander Vennet (2005); Hughes and Moon (2003); Hughes, Mester, and Moon (2001); Hughes, Lang, Mester, Moon, and Pagano (2003); Baele, De Jonghe, and Vander Vennet (2007); and Hughes and Mester (2013a, 2013b).
} 
from its potential is $12(=120-108)$. Its market-value inefficiency ratio is $0.10(=12 / 120)$, and its noise-adjusted Tobin's $q$ ratio is $1.08(=108 / 100)$.

\section{Measuring the Value of Investment Opportunities ${ }^{9}$}

In addition to measuring financial performance, Tobin's $q$ ratio is also used to measure the value of investment opportunities. For example, Yermack (2006) uses the $q$ ratio to measure and control for the value of investment opportunities in regressions intended to explain the personal use of company jets by the CEO. In regressions to explain CEO compensation, Core, Holthausen, and Larcker (1999) use the market-to-book ratio to control for the value of investment opportunities. The accuracy of Tobin's $q$ ratio as a measure of the value of a firm's investment opportunities is compromised when agency problems reduce a firm's market value. To avoid this bias, the measure should be independent of the actions of a firm's management, and it should gauge the highest potential value of a firm's investment opportunities. The stochastic frontier estimation can be used to obtain the highest potential value of assets in the particular markets in which a firm operates. This frontier differs from the frontier in (1) used to estimate the highest potential value over all markets in which firms in the sample operate. In the case of the efficiency frontier (1), a bank's highest potential value is gauged from its peers with the same book-value investment in assets. In the case of the investment opportunity frontier, a bank's peers are not just those of the same size, but also those operating under similar market conditions such as the macroeconomic growth rate and market concentration. Since this frontier is estimated over the entire sample of banks, the estimated highest potential value of the investment opportunities of any individual bank is independent of its own achieved value.

We obtain this potential value by adding variables to the frontier in (1) that capture the economic opportunities of the markets in which a bank operates - the weighted ten-year average

\footnotetext{
9 This section follows the original exposition of Hughes, Lang, Moon, and Pagano (1997), which is restated more recently in Hughes, Mester, and Moon (2016) and Hughes, Jagtiani, and Mester (2016).
} 
GDP growth rate $\left(\right.$ Growth $\left._{\mathrm{i}}\right)$ and the weighted average Herfindahl index of market concentration $\left(\operatorname{Herf}_{\mathrm{i}}\right)$ for these markets, where the weights are deposit shares. We interact both growth and market concentration with the investment in assets, $B V A_{\mathrm{i}}$. Using maximum likelihood estimation, we fit the following equation to banks' market values:

$$
M V A_{\mathrm{i}}=\alpha+\beta_{\mathrm{A}}\left(B V A_{\mathrm{i}}\right)+\gamma_{\mathrm{AA}}\left(B V A_{\mathrm{i}}^{2}\right)+\gamma_{\mathrm{AG}}\left(B V A_{\mathrm{i}}\right)\left(\text { Growth }_{\mathrm{i}}\right)+\gamma_{\mathrm{AH}}\left(B V A_{\mathrm{i}}\right)\left(\operatorname{Herf}_{\mathrm{i}}\right)+\varepsilon_{\mathrm{i}}
$$

where $\varepsilon_{\mathrm{i}}=v_{\mathrm{i}}-\mu_{\mathrm{i}}$ is an error term comprising statistical noise, $v_{\mathrm{i}} \sim$ iid $N\left(0, \sigma_{v}{ }^{2}\right)$, and the systematic shortfall, $\mu_{\mathrm{i}}$, where we assume the shortfall is half-normal, $\mu_{\mathrm{i}}(\geq 0) \sim$ iid $N\left(0, \sigma_{\mu}^{2}\right)$ in the case of the 2007 estimation and exponential, $\mu_{\mathrm{i}}(>0) \sim \theta \exp (-\theta u)$ in the 2013 case. For the 2013 estimation, to improve the fit of the frontier for small banks, we set $\alpha=0$, which implies that a zero book value of assets is associated with a zero market value of assets.

The value of the deterministic kernel of the stochastic frontier, $N F V A_{\mathrm{i}}$, provides the bestpractice value of a firm's investment opportunities in the markets in which it operates:

$$
N F V A_{\mathrm{i}}=\alpha+\beta_{\mathrm{A}}\left(B V A_{\mathrm{i}}\right)+\gamma_{\mathrm{AA}}\left(B V A_{\mathrm{i}}\right)^{2}+\gamma_{\mathrm{AG}}\left(B V A_{\mathrm{i}}\right)\left(\operatorname{Growth}_{\mathrm{i}}\right)+\gamma_{\mathrm{AH}}\left(B V A_{\mathrm{i}}\right)\left(\operatorname{Herf}_{\mathrm{i}}\right) .
$$

We normalize the frontier value obtained in (9) by the book-value investment in assets adjusted to remove goodwill, which we define as the investment opportunity ratio:

$$
\text { investment opportunity ratio } \mathrm{i}_{\mathrm{i}}=N F V A_{\mathrm{i}} / B V A_{\mathrm{i}}
$$

The highest potential value defined over the markets in which a bank operates is its charter value, the value it would obtain in a competitive auction. Its franchise value is its achieved value. Charter value exceeds franchise value when agency problems erode market value.

The efficiency frontier and the investment opportunities frontier differ in how they define a firm's peers for the purpose of estimating the highest potential value of its assets. The frontier that controls only for asset size defines peers broadly by size over firms in all markets in which the industry operates. Thus, market-value inefficiency defined by this frontier identifies market value 
from firms operating in the most valuable markets and penalizes firms operating in less valuable markets - just as capital markets penalize such market disadvantages. On the other hand, the frontier that controls for asset size as well as market conditions estimates potential value for peers of similar size and market opportunities. This value for any firm is generally less than that obtained from the former frontier.

\section{The Data}

We use 2007 data on 219 publicly traded, top-tier bank holding companies and 2013 data on 303 companies to estimate the efficiency frontier and the investment opportunities frontier. Data on ownership and board structure limit the 2007 sample to 142 holding companies and the 2013 sample to 167 companies. Balance-sheet and income statement data are obtained from the Y9-C Call Reports filed quarterly with regulators and available on the website of the Federal Reserve Bank of Chicago. Compustat gives data on market value while the Corporate Library provides data on ownership structure. A list of variables and their definitions is given in Table 1, while summary statistics for 2013 and 2007 are given in Tables 2 and 3, respectively.

\section{Financial Performance and Capital Structure}

To explore the relationship between banks' financial performance and capital structure, we regress performance measured by $\ln$ (market value of assets) and by the market-value inefficiency ratio on capital structure and a set of control variables, including asset size, asset allocation, offbalance-sheet activities, asset quality, ownership structure, and the value of investment opportunities. While the market value of assets measures achieved financial performance and is thus correlated with agency costs, the market-value inefficiency ratio more directly measures agency costs as the difference between best-practice performance and noise-adjusted achieved performance. 


\section{A. Controlling for Capital Structure}

The influence of capital structure can differ between larger and smaller banks. The better diversification of larger banks could imply that, for any given expected return, the lower associated return risk yields a lower risk of insolvency for any given equity capital ratio. To capture this difference, we interact the ratio of equity capital with the log of assets.

The influence of capital structure can also differ between banks with lower- and highervalued investment opportunities. As explained previously, for those with lower-valued opportunities, higher risk-taking might be correlated with higher market value, while, for those with lower-valued opportunities, lower risk-taking might be correlated with higher value. For the former, a higher risk-taking strategy can be associated with a lower capital ratio, and, for the latter, a lower risk-taking strategy, with a higher capital ratio. To capture this possibility, we interact the equity capital ratio with the investment opportunity ratio.

As a result of these interactions of the capital ratio with the log of assets and the investment opportunity ratio, the derivative of performance with respect to the capital ratio will depend not just on the capital ratio but also on the size of the bank and the value of the bank's investment opportunities.

An important component of debt that distinguishes the business strategy of banks is their reliance on deposits. Consequently, we include the ratio of deposits to total borrowed funds.

\section{B. Controlling for Asset Allocation, Off-Balance-Sheet Activities, and Asset Quality}

We account for the consolidated assets of banks by including two terms: the log of the book value of assets and the log squared. We characterize the allocation of assets by the ratio of total loans to assets and the ratio of liquid assets to assets. Liquid assets are defined as the sum of cash, balances at other financial institutions, federal funds sold, securities, and securities sold under agreement to repurchase. Off-balance-sheet activities are represented by the ratio of noninterest 
income to total income. We account for the composition of the loan portfolio with the following ratios: residential real estate loans to assets, commercial real estate loans to assets, consumer loans to assets, and business loans to assets. Loan quality is taken into account by the ratio of nonperforming loans to assets, where nonperforming loans is the sum of past-due and nonaccrual loans, gross charge-offs, and foreclosed real estate owned.

\section{Controlling for Ownership Structure}

Jensen and Meckling (1976) point out that the proportion of outstanding shares owned by an insider represents the insider's price of a dollar of firm value allocated to the insider's private benefit and argue that higher insider ownership increases the price of agency goods and, thus, better aligns the interests of inside owners with those of outside owners - a phenomenon they call the convergence-of-interests hypothesis. Citing a study by Weston (1979) that finds that no firm where insiders own 30 percent or more of outstanding shares has ever been acquired in a hostile takeover, Morck, Shleifer, and Vishny (1988) hypothesize that increased insider ownership enhances insiders' control and makes it more difficult to fire them or to replace them by a hostile takeover - a phenomenon they call entrenchment. They add to the alignment-of-interests hypothesis a second, contrasting one, the entrenchment hypothesis. As insider ownership increases, managers' interests are better aligned with those of outside owners so managers tend to consume fewer agency goods; however, managers also become more entrenched - more difficult to fire - which implies they tend to consume more agency goods. Using U.S. data on firms, Morck, Shleifer, and Vishny (1988) estimate a piece-wise linear relationship between Tobin's $q$ ratio and ownership by officers and directors. For levels of insider ownership between 0 and 5 percent, they find a statistically significant, positive relationship; between 5 and 25 percent, a significant negative relationship; and over 25 percent, weaker evidence of a positive relationship. They interpret the positive signs as evidence that the convergence-of-interests hypothesis dominates entrenchment and the negative sign, that entrenchment dominates convergence. DeYoung, Spong, and Sullivan 
(2001) reach similar conclusions from regressions that relate performance to a quadratic specification of ownership at banks. Hughes and Mester (2013a) use a cubic specification of ownership and find the three regimes of Morck, Shleifer, and Vishny (1988), also at U.S. banks.

These specifications assume that the relationship between performance and a given level of insider ownership is independent of the size of the firm. However, ownership at large financial institutions is limited by the personal wealth of insiders. Thus, the performance incentives of owning 5 percent of outstanding shares at a large bank are likely to differ from those at a small bank. We allow asset size to influence performance incentives by interacting the proportion of outstanding shares owned by insiders and the squared proportion with the logarithmic transformation of asset size. As a result of these interactions, the derivative of performance with respect to insider ownership depends not just on the proportion of insider ownership, but also on the log of asset size and the interaction of insider ownership and the log of asset size.

In addition, the performance incentives created by managerial ownership may differ by the value of investment opportunities the bank experiences. Higher-valued investment opportunities may relieve performance pressures on managers and allow them to consume more agency goods while achieving a relatively high market value. We investigate this incentive by interacting the proportion and the squared proportion of outstanding shares owned by insiders with the investment opportunity ratio. We follow a similar strategy with respect to the proportion of outstanding shares owned by blockholders: we interact this proportion with the log of assets and with the investment opportunity ratio. 


\section{The Performance Equations}

We apply the general-to-specific modeling strategy to identify the best specification for each year's two performance equations. ${ }^{10}$ In each regression, we start with the same general specification, which includes all the explanatory variables described above. The root explanatory variables we consider include the $\ln$ (book value of assets) and $\ln$ (book value of assets) squared; asset quality, measured by the ratio of nonperforming loans to total assets; the proportion of outstanding common shares owned by officers and directors at the end of the prior year interacted with the $\ln$ (book value of assets), and interacted with the investment opportunity ratio; the proportion of outstanding shares owned by blockholders, that is, holders of 5 percent or more of outstanding shares at the end of the prior year interacted with two variables, the $\ln$ (book value of assets) and the investment opportunity ratio; ${ }^{11}$ the ratios of loans to assets, residential real estate loans to assets, commercial real estate loans to assets, consumer loans to assets, and business loans to assets; the ratio of liquid assets to assets; off-balance-sheet activities measured by the ratio of noninterest income to total income; the ratio of deposits to total borrowed funds; and the ratio of equity capital to assets and its interaction with two variables, the $\ln$ (book value of assets) and the investment opportunity ratio. Table 1 gives the definitions of these variables.

Our initial specification includes these 20 control variables and an intercept term. We focus, in part, on the effects of the capital ratio's interaction with asset size and with the value of investment opportunities on performance; consequently, we keep these two variables in the process of applying the general-to-specific modeling strategy. Hence, except for these two variables, we remove the explanatory variable associated with the largest reduction in the Akaike

\footnotetext{
${ }^{10}$ Hendry (1983) provides the first complete application. Campos, Ericsson, and Hendry (2005) give and overview of the technique. Maddala (2001, pp. 483-484) provides a textbook-level introduction to the general-to-specific approach.

11 We used lagged ownership structure to deal with the endogeneity of contemporaneous ownership. In principle, one could address the endogeneity issue using instrumental variables, but we could not determine good instruments that explain ownership but not financial performance.
} 
Information Criterion (AIC), one-by-one sequentially until the AIC stops decreasing. We carry out this strategy for the regressions involving each of the two performance measures for each of the two years. ${ }^{12}$

In summary, the general specifications of the performance equations we estimate are as follows:

$$
P_{\mathrm{i}}=\boldsymbol{a}+\mathbf{X} \boldsymbol{\beta}+\varepsilon_{\mathrm{i}}
$$

where $P_{\mathrm{i}}=$ Performance, as measured by $\ln ($ market value of assets in $\$ 1000 \mathrm{~s})$ and market-value inefficiency, and $\mathbf{X}$ is the set of regressors:

nonperforming loans/assets, insider ownership* $\ln ($ book value of assets in $\$ 1000$ s), insider ownership*investment opportunity ratio, insider ownership squared* $\ln$ (book value of assets in $\$ 1000$ s), insider ownership squared*investment opportunity ratio, blockholder ownership*ln(book value of assets in \$1000s), blockholder ownership*investment opportunity ratio, total loans/total assets, residential real estate loans/total assets, commercial real estate loans/total assets, consumer loans/total assets, business loans/total assets, liquid assets/ total assets, noninterest income/total income, deposits/total borrowed funds,

\footnotetext{
12 For the $2013 \ln$ (market value of assets) regressions, reported in Table 4, the AIC declines from -581.8334 for the general specification to -589.7162 for the final specification. For the 2013 market-value inefficiency regressions, the AIC declines from -655.8724 for the general specification to -664.9186 for the final specification. For the $2007 \ln$ (market value of assets) regressions, reported in Table 8, the AIC declines from -550.9030 for the general specification to -567.2802 for the final specification. For the 2007 market-value inefficiency regressions, the AIC declines from -566.3939 for the general specification to -577.2006 for the final specification.
} 
equity capital/total assets, equity capital ratio* $\ln ($ book value of assets in $\$ 1000$ s), equity capital ratio*investment opportunity ratio, $\ln$ (book value of assets in $\$ 1000$ s), $\ln$ (book value of assets in $\$ 1000$ s) squared.

\section{E. Performance Incentives of Capital Structure: The Two Faces of Equity}

Tables 4 and 8 report the results of the performance regressions for 2013 and 2007, respectively. The general and final specifications are reported for each performance measure. We focus on the two final specifications for each year and, within those specifications, the results for the relationship of performance to the capital strategy.

Based on the estimated parameters reported in Table 4 for 2013, the derivative of $\ln ($ market value of assets $(\$ 1000)$ ) with respect to the capital ratio is:

$\partial \ln ($ market value assets $) / \partial$ capital ratio $=\mathbf{4 . 8 3 1 6 2}+(-\mathbf{0 . 2 3 8 6 4})(\ln ($ book-value assets $(1000 \mathrm{~s}))$ $+(-\mathbf{0 . 6 5 7 2 4})$ (investment-opportunity ratio).

(Coefficients in bold print are statistically different from 0 at a 10 percent or better level.) The estimated value of the derivative is positive for 132 banks and negative for 35 and 97 of the positive values and 15 of the negative values are significantly different from 0 . On the margin, a reduction in the capital ratio at these 15 banks exhibiting a negative value is associated with a higher market value, which suggests that market discipline may work against financial stability at these banks. Table 5 lists these 15 banks in descending order of consolidated assets. Note that each has more than $\$ 50$ billion in assets, which makes them subject to increased regulatory scrutiny under the Dodd-Frank Act.

The comparable derivative when performance at the end of 2013 is measured by marketvalue inefficiency is 
$\partial$ market-value inefficiency $/ \partial$ capital ratio $=\mathbf{- 1 2 . 8 4 0 5 2}+(\mathbf{0 . 4 5 2 8 3})(\ln ($ book-value assets $(1000 \mathrm{~s}))$

$+(4.25213)$ (investment-opportunity ratio).

In this case, 133 banks have a negative value, with 110 being statistically significant, and 33 have a positive value, with 20 being statistically significant. 13 Thus, at the margin, a reduction in the capital ratio at these 20 banks is correlated with reduced market-value inefficiency, which suggests market discipline at these banks could work against financial stability. Table 5 reports these banks in descending order by asset size. Each holds consolidated assets greater than $\$ 50$ billion.

To illustrate, consider the largest bank on the list in Table 5, JPMorgan Chase. The value of the derivative of $\ln$ (market-value assets) with respect to the equity capital ratio is estimated to be -0.99720 , indicating that a decrease in the equity capital ratio of -0.01 is associated with $a+0.997$ percent increase in market value. The next three largest financial institutions exhibit a similar effect. The value of the derivative of market-value inefficiency with respect to the equity capital ratio for JP Morgan Chase is estimated to be 1.29674, indicating that a decrease in the equity capital ratio of -0.01 is associated with a decrease of -0.0129674 in its market-value inefficiency ratio. Two of the next three largest financial institutions exhibit a performance effect of similar magnitude.

Tables 6 and 7 compare the means of key variables for the groups of banks with positive and negative derivatives for 2013. As shown in columns 2 and 5 of Table 6, for the banks whose performance is positively related to their capital ratio (which is the majority), an increase of 0.01 in the capital ratio is associated with an average increase of 0.3970 percent in market value and a 0.4534 percent decrease in market-value inefficiency (that is, with higher efficiency). For banks whose performance is negatively related to their capital ratio (which is a small number of banks), an increase of 0.01 in their capital ratio is associated with an average decrease of 0.6782 percent in

\footnotetext{
${ }^{13}$ We obtained estimates of market-value inefficiency for the 166 observations for which we had data on the
} market value of assets. 
their market value and an average increase of 0.8759 in their market-value inefficiency. Thus, for this small number of banks, there are market incentives to reduce their capital ratios on the margin. But note that the average size of banks in this category is considerably larger than that of banks in the other category that experience the incentive to increase their capital ratio. The 15 banks whose $\ln$ (market value of assets) is negatively related to the capital ratio hold on average $\$ 791.8$ billion in assets as opposed to the 97 with a positive derivative that hold on average $\$ 3.4$ billion in assets. Similarly, the 20 banks whose market-value inefficiency is positively related to the capital ratio hold on average $\$ 614.2$ billion in assets, while the 110 banks with a negative derivative hold on average $\$ 5.1$ billion in assets. The banks whose performance is negatively related to their capital ratio hold more than $\$ 50$ billion in assets, which makes them subject to increased regulatory scrutiny under the Dodd-Frank Act. These large banks on average achieve a lower Tobin's $q$ ratio but also exhibit lower-valued investment opportunities. Nevertheless, they achieve a higher proportion of their potential market value - a lower market-value inefficiency ratio. Hence, it appears that they exploit their lower-valued investment opportunities more effectively. Finally, they hold on average a higher ratio of Tier 1 and Tier 2 capital to assets. ${ }^{14}$ Table 7 compares means of variables that characterize asset allocation, off-balance-sheet activities, and reliance on deposits for these two groups of banks. As expected, these differences reflect the well- known differences between larger and smaller banks.

Tables 8-11 repeat the analysis above using 2007 data. Table 8 reports the results of the performance regressions. The derivative of $\ln ($ market value of assets $(\$ 1000)$ ) with respect to the capital ratio is:

$\partial \ln ($ market value assets $) / \partial$ capital ratio $=0.13844+(\mathbf{- 0 . 1 3 7 0 7})(\ln ($ book-value assets $(1000 \mathrm{~s}))$

$+(\mathbf{1 . 8 0 7 4 2})$ (investment-opportunity ratio).

\footnotetext{
${ }^{14}$ The Tier 1 capital ratio is given by the variable ecap_assets, while the ratio comprising the sum of Tier 1
} and Tier 2 is given by fcap_assets. 
The estimated value of the derivative is positive for 33 banks and negative for 109 , showing that right before the crisis hit, few banks appeared to have a market-driven incentive to increase their capital ratio, while many appeared to experience the opposite incentive. None of the 33 positively valued derivatives is statistically significant; only 29 of the 109 negatively valued derivatives are statistically significant, but these banks are among the largest banks in the sample. Panel A of Table 9 lists the derivatives for the 17 banks whose assets exceeded $\$ 50$ billion in 2007. Note that for all of these banks, their derivatives of performance with respect to the equity capital ratio are statistically significantly negative. Panel B of Table 9 shows all 29 banks with statistically significant negative derivatives, ordered by their statistical significance. The capital-market incentive to reduce the capital ratio extends from the largest banks to much smaller banks. Tables 10 and 11 compare the means of key variables for these 29 banks with those of the 33 banks with positive but statistically insignificant derivatives. These 29 banks are on average much larger and exhibit the typical characteristics of larger banks.

When performance is measured by market-value inefficiency, the derivative of performance with respect to the equity capital ratio is $\partial$ market-value inefficiency $/ \partial$ capital ratio $=-\mathbf{3 . 1 8 1 6 9}+(\mathbf{0 . 2 7 1 7 7})(\ln ($ book-value assets $(1000 \mathrm{~s}))$ $+(-\mathbf{1 . 0 2 5 5 0})$ (investment-opportunity ratio).

The estimated derivative is negative for 96 banks (with 61 of these statistically significant) and positive for 46 banks (with 13 of these statistically significant). Thus, increasing the capital ratio is associated with reduced market-value inefficiency (that is, better performance) at 61 banks. But reducing the capital ratio at the 13 banks with a significant positive derivative is associated with reduced market-value inefficiency. This suggests that market discipline might work against financial stability at these banks to the extent that it gives an incentive to lower capital ratios. As shown in Table 9, all 13 banks with a significant positive derivative had assets greater than $\$ 50$ billion in 2007. 
To illustrate, consider the largest bank on the list in Table 9, Citigroup. The value of the derivative of $\ln$ (market-value assets) with respect to the equity capital ratio is estimated to be -1.07774 , indicating that a decrease in the equity capital ratio of -0.01 is associated with a +1.07774 percent increase in market value. The next two largest financial institutions exhibit a similar effect. The value of the derivative of market-value inefficiency with respect to the equity capital ratio for Citigroup is estimated to be 1.60196, indicating that a decrease in the equity capital ratio of -0.01 is associated with a decrease of -0.0160196 in its market-value inefficiency ratio. The next two largest financial institutions exhibit a performance effect of similar magnitude. These results suggest that the capital market appears to reward riskier capital strategies in 2007.

Of course, our results are based on simple regressions, and there are several caveats that one should apply to avoid over-interpreting these results. In particular, we cannot infer causation from these results. We take the results as merely suggestive of a statistically significant association that calls for further analysis. But we also take them as a caution that one should be careful not to assume that market discipline will drive incentives leading to a more stable financial system. A natural conclusion would be that regulatory capital requirements are necessary.

\section{Conclusions}

Using measures of performance and investment opportunities derived from stochastic frontier analysis and 2007 and 2013 data on top-tier, publicly traded U.S. bank holding companies, we find evidence of two faces of equity investment. At banks with higher-valued investment opportunities, on the margin an increase in their equity capital ratio is associated with better financial performance, while at banks with lower-valued investment opportunities, a marginal decrease in their equity capital ratio is associated with better financial performance. Because the largest U.S. financial institutions tend to have lower-valued investment opportunities, our results suggest that they may have a market-based incentive to reduce their capital ratio. To the extent 
that market discipline rewards reducing the capital ratio among the largest banks, it would tend to undermine financial stability. Our results support the need for regulatory capital requirements. 


\section{Bibliography}

Bank for International Settlements, Basel Committee on Banking Supervision, (September 2001). "Pillar 3 - Market Discipline," Working Papers No 7, http://www.bis.org/publ/bcbs wp7.htm.

Baele, L., De Jonghe, O., and Vander Vennet, R. (2007). Does the stock market value bank diversification? Journal of Banking and Finance 31, 1999-2023.

Bauer, Paul W. (1990). Recent developments in the econometric estimation of frontiers, Journal of Econometrics 46, 39-56.

Calomiris, C.W. and Nissim, D. (2007). Activity-based valuation of bank holding companies, Working Paper 12918, National Bureau of Economic Research.

Campos, J., Ericsson, N.R., and Hendry, D.F. (2005). General-to-specific modeling: an overview and selected bibliography, Introduction in J. Campos, N.R. Ericsson, and David F. Hendry (eds.), Generalto-Specific Modeling, Edward Elgar Publishing, Cheltenham.

Core, J.E., Holthausen, R.W., and Larcker, D.F. (1999). Corporate governance, chief executive officer compensation, and firm performance, Journal of Financial Economics 51, 371-406.

De Jonghe, O. and Vander Vennet, R. (2005). Competition versus agency costs: an analysis of charter values in European banking, Working Paper, Ghent University.

DeYoung, R., Spong, K. and Sullivan, R.J. (2001). Who's minding the store? Motivating and monitoring hired managers at small, closely held commercial banks. Journal of Banking and Finance $25,1209-1243$.

Greenspan, Alan (2005). Risk transfer and financial stability, Remarks to the Federal Reserve Bank of Chicago's Forty-First Annual Conference on Bank Structure, Chicago, IL, May 5, 2005.

Greenspan, Alan (2008). Testimony at the Hearing on rhe Financial Crisis and the Role of Federal Regulators, before the Committee on Oversight and Government Reform, U.S. House of Representatives, October 23, 2008, https://www.gpo.gov/fdsys/pkg/CHRG110hhrg55764/html/CHRG-110hhrg55764.htm.

Grossman, R.S. (1992). Deposit insurance, regulations, and moral hazard in the thrift industry: evidence from the 1930s, American Economic Review 82, 800-821.

Habib, M.A. and Ljungqvist, A. (2005). Firm value and managerial incentives: a stochastic frontier approach, Journal of Business 78, 2053-2093.

Hendry, D.F. (1983). Econometric modelling: the consumption function in retrospect, Scottish Journal of Political Economy 30, 193-220.

Hughes, J.P., Jagtiani, J., and Mester, L.J. (2016). Is bigger necessarily better in community banking? Department of Economics, Rutgers University, Working Paper 201604.

Hughes, J.P., Lang, W., Mester, L.J., and Moon C.-G. (1999). The dollars and sense of bank consolidation, Journal of Banking and Finance 23, 291-324. 
Hughes, J.P., Lang, W., Mester, L.J., Moon C.-G., and Pagano, M. (2003). Do bankers sacrifice value to build empires? Managerial incentives, industry consolidation, and financial performance, Journal of Banking and Finance 27, 417-447.

Hughes, J.P., Lang, W., Moon C.-G. and Pagano, M. (1997). Measuring the efficiency of capital allocation in commercial banking, Working Paper 98-2, Federal Reserve Bank of Philadelphia (revised as Working Paper 2004-1, Rutgers University Economics Department).

Hughes, J.P. and Mester, L.J. (2013a). A primer on market discipline and governance of financial institutions for those in a state of shocked disbelief, Chapter 2 in Efficiency and Productivity Growth: Modelling in the Financial Services Industry, F. Pasiouras (ed.), John Wiley and Sons: West Sussex, U.K., 19-47.

Hughes, J.P. and Mester, L.J. (2013b). Who said large banks don't experience scale economies? Evidence from a risk-return-driven cost function, Journal of Financial Intermediation 22, 559-585.

Hughes, J.P., Mester, L.J. and Moon, C.-G. (2016). Measuring agency costs and the value of investment opportunities of U.S. bank holding companies with stochastic frontier estimation, forthcoming in the Research Handbook on Competition in Banking and Finance, J.A. Bikker and L. Speirdijk (eds.).

Hughes, J.P., Mester, L.J., and Moon, C.-G. (2001). Are scale economies in banking elusive or illusive? Evidence obtained by incorporating capital structure and risk-taking into models of bank production, Journal of Banking and Finance 25, 2169-2208.

Hughes, J.P. and Moon C.-G. (2003). Estimating managers' utility-maximizing demand for agency goods, Working Paper 2003-24, Department of Economics, Rutgers University.

Jensen, M.C. and Meckling, W.H. (1976). Theory of the firm: managerial behavior, agency costs, and ownership structure, Journal of Financial Economics 5, 305-360.

Jondrow, J., Lovell, C.A.K., Materov, I.S., and Schmidt, P. (1982). On the estimation of technical efficiency in the stochastic frontier production function model, Journal of Econometrics 19, 233238.

Keeley, M.C. (1990). Deposit insurance, risk, and market power in banking, American Economic Review 80, 1183-1200.

Laeven, L., and Levine, R. (2009). Bank governance, regulation and risk taking, Journal of Financial Economics 93, 259-275.

Maddala, G.S. (2001). Introduction to Econometrics, Third Edition, Macmillan Publishing Co., New York.

Marcus, A.J. (1984). Deregulation and bank financial policy, Journal of Banking and Finance 8, 557565.

McConnell, J.J. and Servaes, H. (1995). Equity ownership and the two faces of debt, Journal of Financial Economics 39, 131-157. 
Morck, R., Shleifer, R.M. and Vishny, R.W. (1988). Management ownership and market valuation: an empirical analysis, Journal of Financial Economics 20, 293-316.

Nakamoto, M. and Wighton, D. (2007), Citigroup chief stays bullish on buy-outs, Financial Times, July 9, 2007.

Weston, J.F. (1979). The tender takeover, Mergers and Acquisitions, 74-82.

Yermack, D. (2006). Flights of fancy: corporate jets, CEO perquisites, and inferior shareholder returns, Journal of Financial Economics 80, 211-242. 


\section{Figure $1^{15}$}

\section{Market-Value Frontier}

Stochastic frontier estimation yields the potential market value of assets as a quadratic frontier of the book value of assets net of goodwill. The error term, $\varepsilon_{\mathrm{i}}=v_{\mathrm{i}}-\mu_{\mathrm{i}}$, is composed of statistical noise, $v_{\mathrm{i}} \sim$ iid $N\left(0, \sigma_{v}{ }^{2}\right)$, and the systematic shortfall from bank i's highest potential (frontier) market value. For the 2007 data, we adopt the half-normal distribution, $\mu_{\mathrm{i}}(\geq 0) \sim$ iid $N\left(0, \sigma_{\mu}{ }^{2}\right)$, for this shortfall; and for the 2013 data, the exponential distribution, $\left.\mu_{\mathrm{i}}>0\right) \sim \theta \exp (-\theta u)$. The quadratic specification allows the frontier to be nonlinear. In this example, bank i invests 100 in assets and achieves a market value adjusted for statistical noise, $v_{i}$, of 108 . Its highest potential value is 120 . The shortfall of its achieved value from its potential is $12(=120-108)$. Its market-value inefficiency ratio is $0.10(=12 / 120)$, and its noise-adjusted Tobin's $q$ ratio is $1.08(=108 / 100)$.

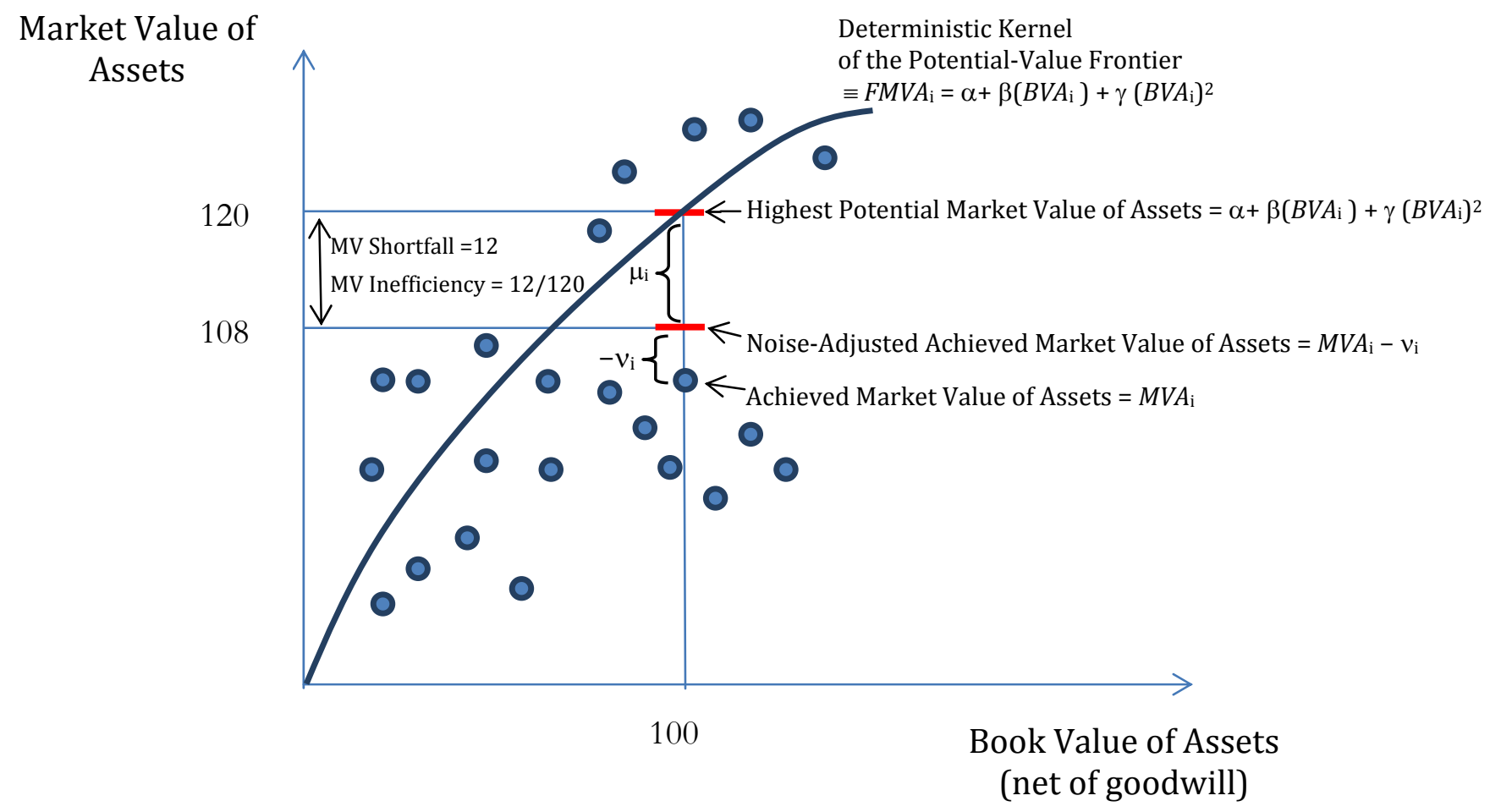

15 This figure is from Hughes, Jagtiani, and Mester (2016) and also appears in Hughes, Mester, and Moon (2016). 


\section{Table 1}

\section{Data Definitions}

Book-value of assets represents book value (thousands) of total consolidated assets at the end of the year. Adjusted book value is obtained by subtracting goodwill from book value to remove components derived from market value. The market value of assets is proxied by the ratio of the sum of the book value of liabilities and the market value of equity to the adjusted book value of assets.

The market-value inefficiency ratio is a measure of relative agency costs given by the difference between the highest potential value of a bank's assets over all markets found in the sample and the bank's noise-adjusted achieved market value (lost market value) divided by the highest potential value of assets over all markets, which is estimated by a stochastic frontier technique. The value of a BHC's investment opportunities is measured by fitting a stochastic frontier to the market value of assets as a function of the book value of assets and, in the bank's local markets, the marketweighted, 10-year average macroeconomic growth rate and the BHC's market-weighted Herfindahl index of concentration. The investment opportunity ratio is the highest potential value of the bank's assets in the markets in which it operates divided by the book value of assets adjusted to remove goodwill.

Tobin's $q$ ratio is the ratio of the market value of assets to the adjusted book value of assets where the market value of assets is proxied by the sum of the market value of equity and the book value of liabilities. The noise-adjusted Tobin's $q$ ratio is market value of assets less statistical noise derived from stochastic frontier estimation.

The nonperforming assets ratio is the sum of past-due and nonaccrual loans, gross charge-offs, and foreclosed real estate owned divided by total assets.

Liquid assets are defined as the sum of cash, balances at other financial institutions, federal funds sold, securities, and securities sold under agreement to repurchase.

The ratio of equity capital to assets is given by the sum of common stock, retained earnings, and perpetual preferred stock divided by total assets. The ratio of financial capital to assets is the sum of equity capital, loan-loss reserves, and subordinated debt divided by total assets.

Insider ownership is the proportion of outstanding shares owned by officers and directors in the year before, i.e., in 2006 or 2012. Blockholder ownership is the percent of outstanding shares held by blockholders (holders of 5 percent or more of outstanding shares based on 13D filings) at year-end 2006 or 2012. 
Table 2

2013 Data: Summary Statistics

The data set includes 167 publicly traded top-tier bank holding companies at the end of 2013.

Panel A: Assets and Financial Performance

\begin{tabular}{|l|c|c|c|c|c|c|}
\hline & $\boldsymbol{N}$ & Mean & Median & Std. Dev. & $\begin{array}{c}\text { Minimu } \\
\mathbf{m}\end{array}$ & Maximum \\
\hline Book Value Assets (1,000s) & 167 & $81,361,076$ & $6,039,126$ & $322,211,407$ & 711,515 & $2,415,689,000$ \\
\hline Investment Opportunity Ratio & 167 & 1.271 & 1.261 & 0.103 & 0.988 & 1.620 \\
\hline Tobin's q Ratio & 167 & 1.072 & 1.065 & 0.055 & 0.926 & 1.313 \\
\hline Noise-Adjusted Tobin's q Ratio & 166 & 1.073 & 1.071 & 0.039 & 0.943 & 1.199 \\
\hline Market-Value Inefficiency & 166 & 0.169 & 0.144 & 0.107 & 0.000 & 0.479 \\
\hline
\end{tabular}

Panel B: Capital Structure and Asset Quality

\begin{tabular}{|c|c|c|c|c|c|c|}
\hline $\begin{array}{c}\text { Book-Value Equity/ } \\
\text { Total Assets }\end{array}$ & 167 & 0.113 & 0.112 & 0.025 & 0.069 & 0.229 \\
\hline $\begin{array}{c}\text { (Equity + Sub Debt + Loan Loss } \\
\text { Reserves)/ Total Assets }\end{array}$ & 167 & 0.126 & 0.125 & 0.026 & 0.076 & 0.241 \\
\hline $\begin{array}{c}\text { Deposits/(Deposits + Other } \\
\text { Borrowed Funds) }\end{array}$ & 167 & 0.876 & 0.909 & 0.144 & 0.104 & 1.000 \\
\hline Nonperforming Loans/Total Assets & 167 & 0.021 & 0.018 & 0.017 & 0.000 & 0.166 \\
\hline \multicolumn{7}{|c|}{ Panel C: Ownership Structure } \\
\hline Officer and Director Ownership & 167 & 0.094 & 0.056 & 0.119 & 0.000 & 0.722 \\
\hline Blockholder Ownership & 167 & 0.185 & 0.166 & 0.118 & 0.000 & 0.867 \\
\hline
\end{tabular}

Panel D: Asset Allocation and Off-Balance-Sheet Activities

\begin{tabular}{|c|c|c|c|c|c|c|}
\hline Liquid Assets/ Assets & 167 & 0.282 & 0.248 & 0.124 & 0.019 & 0.785 \\
\hline $\begin{array}{c}\text { Noninterest Income/ } \\
\text { Total Revenue }\end{array}$ & 167 & 0.259 & 0.237 & 0.195 & -1.129 & 0.928 \\
\hline Total Loans/Total Assets & 167 & 0.633 & 0.658 & 0.148 & 0.055 & 0.962 \\
\hline $\begin{array}{c}\text { Residential Real Estate Loans/Total } \\
\text { Assets }\end{array}$ & 167 & 0.199 & 0.195 & 0.109 & 0.000 & 0.631 \\
\hline $\begin{array}{c}\text { Commercial Real Estate Loans/Total } \\
\text { Assets }\end{array}$ & 167 & 0.229 & 0.227 & 0.122 & 0.000 & 0.592 \\
\hline Consumer Loans/Total Assets & 167 & 0.041 & 0.016 & 0.077 & 0.000 & 0.823 \\
\hline Business Loans/Total Assets & 167 & 0.121 & 0.102 & 0.082 & 0.000 & 0.408 \\
\hline
\end{tabular}


Table 3

2007 Data: Summary Statistics

The data set includes 142 publicly traded top-tier bank holding companies at the end of 2007 .

Panel A: Assets and Financial Performance

\begin{tabular}{|c|c|c|c|c|c|c|}
\hline & $n$ & Mean & Median & Std. Dev. & $\begin{array}{c}\text { Minimu } \\
\mathbf{m}\end{array}$ & Maximum \\
\hline Book Value Assets $(1,000 \mathrm{~s})$ & 142 & $57,427,092$ & $4,088,173$ & $269,582,515$ & 659,896 & $2,187,631,104$ \\
\hline Investment Opportunity Ratio & 142 & 1.103 & 1.094 & 0.035 & 1.025 & 1.185 \\
\hline Tobin's $q$ Ratio & 142 & 1.071 & 1.066 & 0.043 & 0.978 & 1.230 \\
\hline Noise-Adjusted Tobin's $q$ Ratio & 142 & 1.069 & 1.066 & 0.039 & 0.983 & 1.200 \\
\hline Market-Value Inefficiency & 142 & 0.308 & 0.314 & 0.162 & 0.000 & 0.719 \\
\hline \multicolumn{7}{|c|}{ Panel B: Capital Structure and Asset Quality } \\
\hline $\begin{array}{c}\text { Book-Value Equity/ } \\
\text { Total Assets } \\
\end{array}$ & 142 & 0.095 & 0.094 & 0.020 & 0.052 & 0.176 \\
\hline $\begin{array}{c}\text { (Equity + Sub Debt + Loan Loss } \\
\text { Reserves)/ Total Assets }\end{array}$ & 142 & 0.110 & 0.109 & 0.022 & 0.063 & 0.182 \\
\hline $\begin{array}{l}\text { Deposits/(Deposits + Other } \\
\text { Borrowed Funds) }\end{array}$ & 142 & 0.814 & 0.830 & 0.127 & 0.145 & 0.991 \\
\hline $\begin{array}{c}\text { Nonperforming Loans/Total } \\
\text { Assets }\end{array}$ & 142 & 0.017 & 0.014 & 0.013 & 0.001 & 0.101 \\
\hline \multicolumn{7}{|c|}{ Panel C: Ownership Structure } \\
\hline Officer and Director Ownership & 142 & 0.120 & 0.077 & 0.134 & 0.000 & 0.694 \\
\hline Blockholder Ownership & 142 & 0.098 & 0.078 & 0.102 & 0.000 & 0.725 \\
\hline \multicolumn{7}{|c|}{ Panel D: Asset Allocation and Off-Balance-Sheet Activities } \\
\hline Liquid Assets/ Assets & 142 & 0.215 & 0.192 & 0.091 & 0.034 & 0.555 \\
\hline $\begin{array}{c}\text { Noninterest Income/ } \\
\text { Total Revenue }\end{array}$ & 142 & 0.179 & 0.162 & 0.081 & 0.038 & 0.496 \\
\hline Total Loans/Total Assets & 142 & 0.702 & 0.723 & 0.102 & 0.356 & 0.885 \\
\hline $\begin{array}{l}\text { Residential Real Estate } \\
\text { Loans/Total Assets }\end{array}$ & 142 & 0.220 & 0.219 & 0.099 & 0.023 & 0.526 \\
\hline $\begin{array}{c}\text { Commercial Real Estate } \\
\text { Loans/Total Assets }\end{array}$ & 142 & 0.269 & 0.264 & 0.130 & 0.005 & 0.663 \\
\hline Consumer Loans/Total Assets & 142 & 0.047 & 0.032 & 0.042 & 0.001 & 0.216 \\
\hline Business Loans/Total Assets & 142 & 0.134 & 0.120 & 0.078 & 0.023 & 0.463 \\
\hline
\end{tabular}




\section{Table 4}

\section{Financial Performance Regressions}

The data represent 167 top-tier, publicly traded U. S. bank holding companies at year-end 2013. The data are obtained from the Y9-C Call Reports, Compustat, and the Corporate Library. Performance is measured by the $\ln$ (market value of assets) and market-value inefficiency. Regressions are estimated with OLS, and standard errors are heteroscedasticity consistent. Definitions of the variables are given in Table 1.

\begin{tabular}{|c|c|c|c|c|c|c|c|c|}
\hline \multirow[b]{4}{*}{ Variable } & \multicolumn{8}{|c|}{ Dependent Variable } \\
\hline & \multicolumn{4}{|c|}{ In(Market Value of Assets) } & \multicolumn{4}{|c|}{ Market-Value Inefficiency } \\
\hline & \multicolumn{2}{|c|}{ General Specification } & \multicolumn{2}{|c|}{ Final Specification } & \multicolumn{2}{|c|}{ General Specification } & \multicolumn{2}{|c|}{ Final Specification } \\
\hline & $\begin{array}{l}\text { Parameter } \\
\text { Estimate }\end{array}$ & $\operatorname{Pr}>|t|$ & $\begin{array}{l}\text { Parameter } \\
\text { Estimate }\end{array}$ & $\operatorname{Pr}>|t|$ & $\begin{array}{l}\text { Parameter } \\
\text { Estimate }\end{array}$ & $\operatorname{Pr}>|t|$ & $\begin{array}{l}\text { Parameter } \\
\text { Estimate }\end{array}$ & $\operatorname{Pr}>|t|$ \\
\hline Intercept & -0.14431 & 0.7328 & -0.29960 & 0.0849 & 4.41800 & $<0.0001$ & 4.66226 & $<0.0001$ \\
\hline $\begin{array}{l}\text { Nonperforming } \\
\text { Loans/Assets }\end{array}$ & -0.52670 & 0.0023 & -0.58965 & 0.0001 & 0.42848 & 0.0160 & 0.41012 & 0.0112 \\
\hline $\begin{array}{l}\text { Managerial Ownership } \\
\times \ln (\text { B.V. Assets) }\end{array}$ & 0.09900 & 0.0071 & 0.09287 & 0.0086 & -0.07219 & 0.0169 & -0.01517 & $<0.0001$ \\
\hline $\begin{array}{l}\text { Managerial Ownership } \\
\times \text { Inv't Opp'ty Ratio }\end{array}$ & -1.02906 & 0.0177 & -0.94935 & 0.0204 & 0.71128 & 0.0441 & & \\
\hline $\begin{array}{l}\text { Managerial Ownership } 2 \\
\times \ln (\text { B.V. Assets) }\end{array}$ & -0.11904 & 0.0212 & -0.11285 & 0.0239 & 0.11877 & 0.0087 & 0.03014 & $<0.0001$ \\
\hline $\begin{array}{l}\text { Managerial Ownership }{ }^{2} \\
\times \text { Inv't Opp'ty Ratio }\end{array}$ & 1.06986 & 0.0836 & 0.99316 & 0.0923 & -1.11336 & 0.0391 & & \\
\hline $\begin{array}{l}\text { Blockholder Ownership } \\
\times \ln \text { (B.V. Assets) }\end{array}$ & 0.00203 & 0.8093 & & & 0.00751 & 0.4137 & 0.00282 & 0.0435 \\
\hline $\begin{array}{l}\text { Blockholder Ownership } \\
\times \text { Inv't Opp'ty Ratio }\end{array}$ & -0.05257 & 0.5818 & -0.03351 & 0.0838 & -0.05700 & 0.6017 & & \\
\hline Loans/Assets & 0.38694 & $<0.0001$ & 0.30128 & $<0.0001$ & -0.08701 & 0.3181 & & \\
\hline $\begin{array}{l}\text { Residential Real Estate } \\
\text { Loans/Assets }\end{array}$ & -0.29420 & $<0.0001$ & -0.25281 & $<0.0001$ & 0.08081 & 0.0354 & & \\
\hline $\begin{array}{l}\text { Commercial Real Estate } \\
\text { Loans/Assets }\end{array}$ & -0.14888 & 0.0023 & -0.11629 & 0.0043 & 0.05012 & 0.1493 & & \\
\hline Consumer Loans/Assets & -0.07224 & 0.2171 & & & 0.00900 & 0.8771 & & \\
\hline Business Loans/Assets & -0.30346 & $<0.0001$ & -0.25269 & $<0.0001$ & 0.14150 & 0.0074 & 0.05449 & 0.1119 \\
\hline Liquid Assets/Assets & 0.17951 & 0.0774 & 0.13567 & 0.0986 & 0.00967 & 0.9146 & & \\
\hline $\begin{array}{l}\text { Noninterest Income/Total } \\
\text { Income }\end{array}$ & 0.01632 & 0.4145 & & & -0.01015 & 0.5246 & & \\
\hline $\begin{array}{l}\text { Deposits/Total Borrowed } \\
\text { Funds }\end{array}$ & -0.00973 & 0.7186 & & & -0.06009 & 0.0428 & -0.07357 & 0.0116 \\
\hline Equity Capital/Assets & 4.09352 & 0.1405 & 4.83162 & 0.0535 & -12.24445 & $<0.0001$ & -12.84052 & $<0.0001$ \\
\hline $\begin{array}{l}\text { Equity Capital/Assets } \\
\times \ln \text { (B.V. Assets) }\end{array}$ & -0.18899 & 0.0823 & -0.23864 & 0.0141 & 12.84052 & $<0.0001$ & 0.45283 & $<0.0001$ \\
\hline $\begin{array}{l}\text { Equity Capital/Assets } \\
\times \text { Inv't Opp'ty Ratio }\end{array}$ & -0.67394 & 0.4656 & -0.65724 & 0.4311 & 4.03722 & $<0.0001$ & 4.25213 & $<0.0001$ \\
\hline $\ln$ (B.V. Assets) & 0.99567 & $<0.0001$ & 1.01369 & $<0.0001$ & -0.42580 & $<0.0001$ & -0.45100 & $<0.0001$ \\
\hline$(\ln (\text { B.V. Assets }))^{2}$ & 0.0003460 & 0.8086 & & & 0.01015 & $<0.0001$ & 0.01080 & $<0.0001$ \\
\hline $\begin{array}{l}\text { Number }+, \text { - Capital Ratio } \\
\text { Derivatives }\end{array}$ & & & $132+, 35-$ & & & & $33+, 133-$ & \\
\hline \multirow[t]{2}{*}{$\begin{array}{l}\text { Number +, - Statistically } \\
\text { Significant Capital Ratio } \\
\text { Derivatives }\end{array}$} & & & $97+, 15-$ & & & & $20+, 110-$ & \\
\hline & $\begin{array}{c}\text { Adj. } \\
\mathrm{R}^{2}=0.999\end{array}$ & $\mathrm{~N}=167$ & $\begin{array}{c}\text { Adj. } \\
\mathrm{R}^{2}=0.999\end{array}$ & $\mathrm{~N}=167$ & $\begin{array}{c}\text { Adj. } \\
\mathrm{R}^{2}=0.914\end{array}$ & $\mathrm{~N}=166$ & $\begin{array}{c}\text { Adj. } \\
\mathrm{R}^{2}=0.914\end{array}$ & $N=166$ \\
\hline
\end{tabular}




\section{Table 5 \\ Derivative of Performance with Respect to Equity Capital Ratio for 2013 Banks Subject to Enhanced Prudential Supervision Under the Dodd-Frank Act}

The full sample consists of 167 publicly traded, top-tier, U. S. bank holding companies at year-end 2013. The data are obtained from the Y9-C Call Reports, Compustat, and the Corporate Library. Performance is measured by the $\ln$ (market value of assets) and market-value inefficiency. The value of the derivatives of $\ln$ (market value assets (1000s)) and market-value inefficiency with respect to equity capital is given for the 21 banks whose consolidated assets exceed $\$ 50$ billion in 2013, which subjects them to enhanced prudential supervision under the 2010 DoddFrank Act.

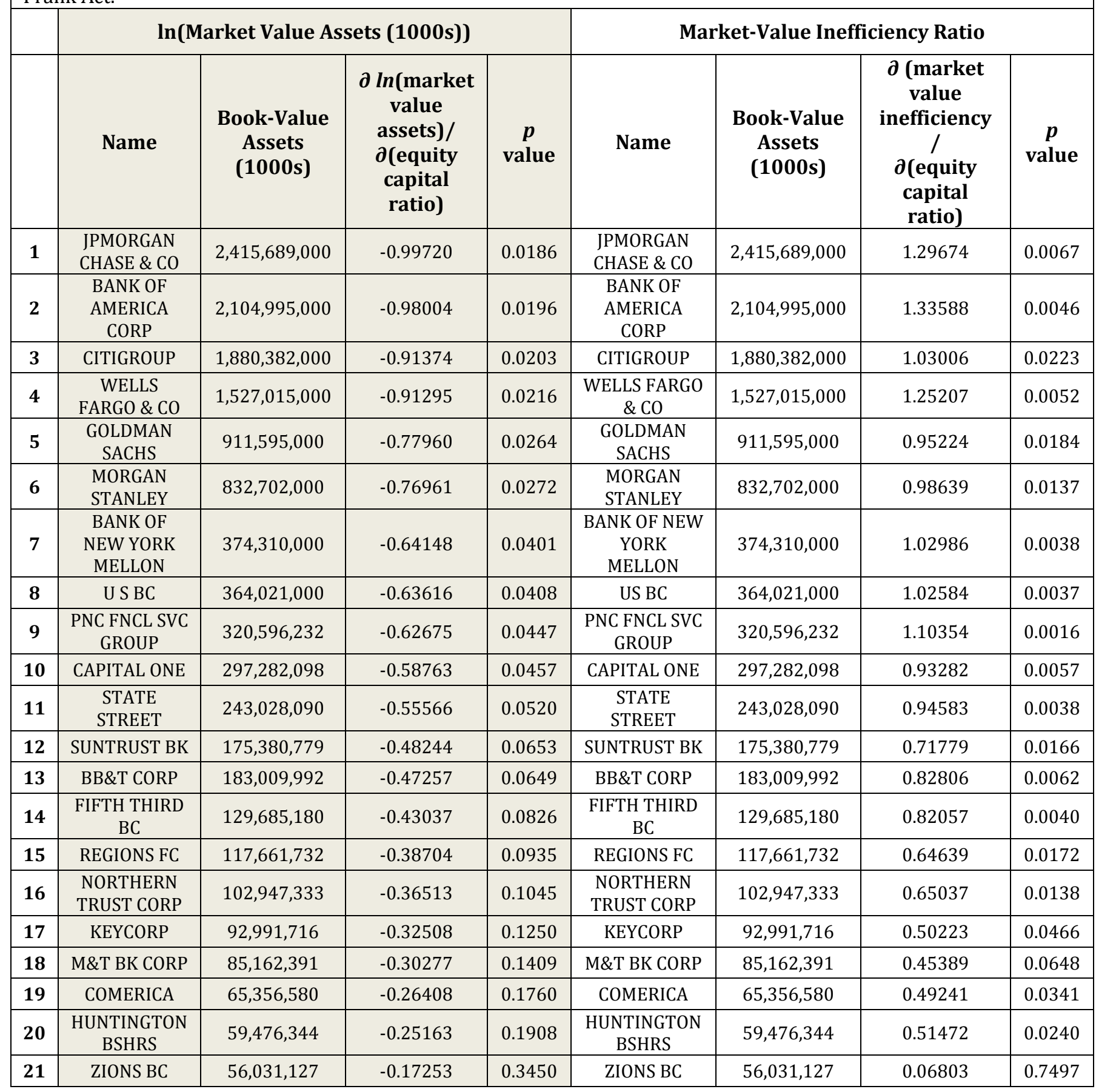


Table 6

Comparisons of Financial Performance in 2013 for Banks with Significantly Positive and Negative Derivatives of Financial Performance with Respect to Equity Capital Ratio

The data set includes 167 publicly traded top-tier bank holding companies at the end of 2013. The $p$ value represents the statistical significance of the comparison of means in the pairing. Pairs of means in bold are statistically different at stricter than $p=0.10$.

\begin{tabular}{|c|c|c|c|c|c|c|}
\hline & \multicolumn{3}{|c|}{$\begin{array}{c}\partial \ln (\text { Market Value of Assets) } / \partial \text { Capital } \\
\text { Ratio }\end{array}$} & \multicolumn{3}{|c|}{$\partial$ Market-Value Inefficiency/ $\partial$ Capital Ratio } \\
\hline & $\begin{array}{c}>0 \\
\mathrm{~N}=97\end{array}$ & $\begin{array}{c}<0 \\
\mathrm{~N}=15\end{array}$ & & $\begin{array}{c}<0 \\
N=110\end{array}$ & $\begin{array}{c}>0 \\
\mathrm{~N}=20\end{array}$ & \\
\hline & Mean & Mean & $\boldsymbol{P}$ & Mean & Mean & $\boldsymbol{P}$ \\
\hline $\begin{array}{l}\text { DPerformance/ } \\
\text { DCapital Ratio }\end{array}$ & 0.3970 & -0.6782 & $<0.0001$ & -0.4534 & 0.8759 & $<0.0001$ \\
\hline $\begin{array}{l}\text { Book Value Assets } \\
(1,000 \mathrm{~s})\end{array}$ & $3,446,971$ & $791,823,540$ & 0.0018 & $5,050,993$ & $614,164,373$ & 0.0018 \\
\hline $\begin{array}{c}\text { Investment } \\
\text { Opportunity Ratio }\end{array}$ & 1.3326 & 1.1245 & $<0.0001$ & 1.2932 & 1.1447 & $<0.0001$ \\
\hline Tobin's $q$ Ratio & 1.0751 & 1.0372 & 0.0012 & 1.0775 & 1.0411 & 0.0002 \\
\hline $\begin{array}{l}\text { Noise-Adjusted Tobin's } \\
\quad q \text { Ratio }\end{array}$ & 1.0751 & 1.0375 & 0.0002 & 1.0795 & 1.0418 & $<0.0001$ \\
\hline $\begin{array}{l}\text { Market-Value } \\
\text { Inefficiency Ratio }\end{array}$ & 0.2334 & 0.0536 & $<0.0001$ & 0.1954 & 0.0579 & $<0.0001$ \\
\hline $\begin{array}{l}\text { Book-Value Equity/ } \\
\text { Total Assets }\end{array}$ & 0.1105 & 0.1097 & 0.9039 & 0.1098 & 0.1089 & 0.8453 \\
\hline $\begin{array}{c}\text { (Equity + Sub Debt + } \\
\text { Loan Loss Reserves)/ } \\
\text { Total Assets }\end{array}$ & 0.1211 & 0.1331 & 0.0793 & 0.1205 & 0.1340 & 0.0098 \\
\hline $\begin{array}{l}\text { Nonperforming } \\
\text { Loans/Total Assets }\end{array}$ & 0.0201 & 0.0214 & 0.7341 & 0.0210 & 0.0201 & 0.8437 \\
\hline
\end{tabular}


Table 7

Comparisons of Balance Sheets in 2013 for Banks with Significantly Positive and Negative Derivatives of Financial Performance with Respect to Equity Capital Ratio

The data set includes 167 publicly traded top-tier bank holding companies at the end of 2013. The $p$ value represents the statistical significance of the comparison of means in the pairing. Pairs of means in bold are statistically different at stricter than $p=0.10$.

\begin{tabular}{|c|c|c|c|c|c|c|}
\hline & \multicolumn{3}{|c|}{ 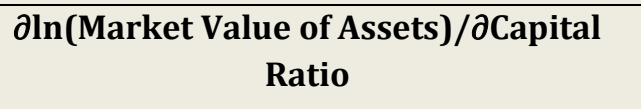 } & \multicolumn{3}{|c|}{$\partial$ Market-Value Inefficiency/ $\partial$ Capital Ratio } \\
\hline & $\begin{array}{c}>0 \\
\mathrm{~N}=97\end{array}$ & $\begin{array}{c}<0 \\
\mathrm{~N}=15\end{array}$ & & $\begin{array}{c}<0 \\
N=110\end{array}$ & $\begin{array}{c}>0 \\
\mathrm{~N}=20\end{array}$ & \\
\hline & Mean & Mean & $p$ & Mean & Mean & $\boldsymbol{P}$ \\
\hline $\begin{array}{c}\text { Book Value Assets } \\
(1,000 \mathrm{~s})\end{array}$ & $3,446,971$ & $791,823,540$ & 0.0018 & $5,050,993$ & $614,164,373$ & 0.0018 \\
\hline $\begin{array}{c}\text { Deposits/ } \\
\text { (Deposits + Other } \\
\text { Borrowed Funds) } \\
\end{array}$ & 0.9186 & 0.6242 & 0.0012 & 0.9122 & 0.6721 & 0.0012 \\
\hline $\begin{array}{l}\text { Noninterest Income/ } \\
\text { Total Revenue }\end{array}$ & 0.1994 & 0.4913 & $<0.0001$ & 0.2078 & 0.4762 & $<0.0001$ \\
\hline Liquid Assets/ Assets & 0.2721 & 0.3601 & 0.0850 & 0.2699 & 0.3439 & 0.0938 \\
\hline $\begin{array}{c}\text { Total Loans/Total } \\
\text { Assets }\end{array}$ & 0.6633 & 0.4473 & 0.0050 & 0.6613 & 0.4907 & 0.0060 \\
\hline $\begin{array}{l}\text { Residential Real Estate } \\
\text { Loans/Total Assets }\end{array}$ & 0.2207 & 0.1370 & 0.0074 & 0.2125 & 0.1424 & 0.0080 \\
\hline $\begin{array}{c}\text { Commercial Real } \\
\text { Estate Loans/Total } \\
\text { Assets }\end{array}$ & 0.2778 & 0.0521 & $<0.0001$ & 0.2780 & 0.0711 & $<0.0001$ \\
\hline $\begin{array}{c}\text { Consumer Loans/Total } \\
\text { Assets }\end{array}$ & 0.0288 & 0.0862 & 0.0264 & 0.0294 & 0.0779 & 0.0162 \\
\hline $\begin{array}{c}\text { Business Loans/Total } \\
\text { Assets }\end{array}$ & 0.1026 & 0.0996 & 0.8878 & 0.1120 & 0.1274 & 0.5234 \\
\hline
\end{tabular}




\section{Table 8}

\section{Financial Performance Regressions}

The data represent 142 top-tier, publicly traded U. S. bank holding companies at year-end 2007. The data are obtained from the Y9-C Call Reports, Compustat, and the Corporate Library. Performance is measured by the $\ln$ (market value of assets) and market-value inefficiency. Regressions are estimated with OLS, and standard errors are heteroscedasticity consistent. Definitions of the variables are given in Table 1.

\begin{tabular}{|c|c|c|c|c|c|c|c|c|}
\hline \multirow{4}{*}{ Variable } & \multicolumn{8}{|c|}{ Dependent Variable } \\
\hline & \multicolumn{4}{|c|}{ ln(Market Value of Assets) } & \multicolumn{4}{|c|}{ Market-Value Inefficiency } \\
\hline & \multicolumn{2}{|c|}{ General Specification } & \multicolumn{2}{|c|}{ Final Specification } & \multicolumn{2}{|c|}{ General Specification } & \multicolumn{2}{|c|}{ Final Specification } \\
\hline & $\begin{array}{c}\text { Parameter } \\
\text { Estimate }\end{array}$ & $\operatorname{Pr}>|t|$ & $\begin{array}{l}\text { Parameter } \\
\text { Estimate }\end{array}$ & $\operatorname{Pr}>|t|$ & $\begin{array}{l}\text { Parameter } \\
\text { Estimate }\end{array}$ & $\operatorname{Pr}>|t|$ & $\begin{array}{l}\text { Parameter } \\
\text { Estimate }\end{array}$ & $\operatorname{Pr}>|t|$ \\
\hline Intercept & 0.13844 & 0.7533 & -0.05189 & 0.8545 & 7.31855 & $<0.0001$ & 7.34252 & $<0.0001$ \\
\hline $\begin{array}{l}\text { Nonperforming } \\
\text { Loans/Assets }\end{array}$ & -0.67809 & 0.0088 & -0.66483 & 0.0099 & 0.75173 & $<0.0001$ & 0.76133 & $<0.0001$ \\
\hline $\begin{array}{l}\text { Managerial Ownership } \\
\times \ln \text { (B.V. Assets) }\end{array}$ & 0.03316 & 0.6017 & & & -0.19395 & 0.0063 & -0.18588 & 0.0086 \\
\hline $\begin{array}{l}\text { Managerial Ownership } \\
\times \text { Inv't Opp'ty Ratio }\end{array}$ & -0.45266 & 0.6027 & & & 2.53973 & 0.0079 & 2.42871 & 0.0105 \\
\hline $\begin{array}{l}\text { Managerial Ownership } 2 \\
\times \ln \text { (B.V. Assets) }\end{array}$ & -0.04628 & 0.6356 & -0.00481 & 0.0148 & 0.27328 & 0.0084 & 0.25987 & 0.0133 \\
\hline $\begin{array}{l}\text { Managerial Ownership }{ }^{2} \\
\times \text { Inv't Opp'ty Ratio }\end{array}$ & 0.56530 & 0.6741 & & & -3.53148 & 0.0130 & -3.34379 & 0.0199 \\
\hline $\begin{array}{l}\text { Blockholder Ownership } \\
\times \ln \text { (B.V. Assets) }\end{array}$ & -0.00580 & 0.7327 & & & 0.05921 & 0.0007 & 0.05778 & $<0.0001$ \\
\hline $\begin{array}{l}\text { Blockholder Ownership } \\
\times \text { Inv't Opp'ty Ratio }\end{array}$ & 0.06358 & 0.8062 & & & -0.84565 & 0.0008 & -0.82201 & 0.0001 \\
\hline Loans/Assets & 0.38876 & 0.0094 & 0.36718 & 0.0006 & 0.12573 & 0.4033 & 0.07407 & 0.0229 \\
\hline $\begin{array}{l}\text { Residential Real Estate } \\
\text { Loans/Assets }\end{array}$ & 0.00466 & 0.9535 & & & -0.01902 & 0.8100 & & \\
\hline $\begin{array}{l}\text { Commercial Real Estate } \\
\text { Loans/Assets }\end{array}$ & -0.01280 & 0.8554 & & & -0.00864 & 0.9011 & & \\
\hline Consumer Loans/Assets & 0.13241 & 0.2500 & 0.10526 & 0.1690 & -0.13041 & 0.1297 & -0.13423 & 0.0601 \\
\hline Business Loans/Assets & 0.01654 & 0.8791 & & & 0.00795 & 0.9314 & & \\
\hline Liquid Assets/Assets & 0.43322 & 0.0007 & 0.43352 & 0.0002 & 0.04819 & 0.7105 & & \\
\hline $\begin{array}{l}\text { Noninterest } \\
\text { Income/Total Income }\end{array}$ & 0.21069 & $<0.0001$ & 0.21166 & $<0.0001$ & -0.01514 & 0.7332 & & \\
\hline $\begin{array}{l}\text { Deposits/Total } \\
\text { Borrowed Funds }\end{array}$ & -0.04135 & 0.2873 & & & -0.01087 & 0.7687 & & \\
\hline Equity Capital/Assets & -1.17943 & 0.5936 & & & -2.87239 & 0.2571 & -3.18169 & 0.2045 \\
\hline $\begin{array}{l}\text { Equity Capital/Assets } \\
\times \ln \text { (B.V. Assets) }\end{array}$ & -0.10135 & 0.2957 & -0.13707 & 0.0069 & 0.27304 & 0.0302 & 0.27177 & 0.0265 \\
\hline $\begin{array}{l}\text { Equity Capital/Assets } \\
\times \text { Inv't Opp'ty Ratio }\end{array}$ & 2.42668 & 0.0310 & 1.80742 & 0.0093 & -1.27077 & 0.2608 & -1.02550 & 0.3608 \\
\hline $\ln ($ B.V. Assets) & 0.94103 & $<0.0001$ & 0.95667 & $<0.0001$ & -0.75182 & $<0.0001$ & -0.75002 & $<0.0001$ \\
\hline$\left(\ln (\text { B.V. Assets) })^{2}\right.$ & 0.00192 & 0.1910 & 0.00164 & 0.1521 & 0.01891 & $<0.0001$ & 0.01884 & $<0.0001$ \\
\hline $\begin{array}{l}\text { Number }+, \text { - Capital } \\
\text { Ratio Derivatives }\end{array}$ & & & $\begin{array}{c}33+, 109 \\
-\end{array}$ & & & & $46+, 96-$ & \\
\hline \multirow[t]{2}{*}{$\begin{array}{l}\text { Number }+, \text { - Statistically } \\
\text { Significant Capital Ratio } \\
\text { Derivatives }\end{array}$} & & & $0+, 29-$ & & & & $13+, 61-$ & \\
\hline & $\begin{array}{c}\text { Adj. } \\
\mathrm{R}^{2}=0.999\end{array}$ & $N=142$ & $\begin{array}{c}\text { Adj. } \\
\mathrm{R}^{2}=0.999\end{array}$ & $N=142$ & $\begin{array}{c}\text { Adj. } \\
\mathrm{R}^{2}=0.964\end{array}$ & $\mathrm{~N}=142$ & $\begin{array}{l}\text { Adj. } \\
\mathrm{R}^{2}=0.966\end{array}$ & $\mathrm{~N}=142$ \\
\hline
\end{tabular}




\section{Table 9}

\section{Derivative of Performance with Respect to Equity Capital Ratio}

\section{for 2007 Banks Subject to Enhanced Prudential Supervision Under the Dodd-Frank Act}

The full sample consists of 142 publicly traded, top-tier, U.S. bank holding companies at year-end 2007. The data are obtained from the Y9-C Call Reports, Compustat, and the Corporate Library. Performance is measured by the $\ln$ (market value of assets) and market-value inefficiency. The value of the derivatives of $\ln$ (market value assets (1000s)) and market-value inefficiency with respect to equity capital is given for the 17 banks whose consolidated assets exceed $\$ 50$ billion in 2007, which subjects them to enhanced prudential supervision under the 2010 DoddFrank Act.

Panel A

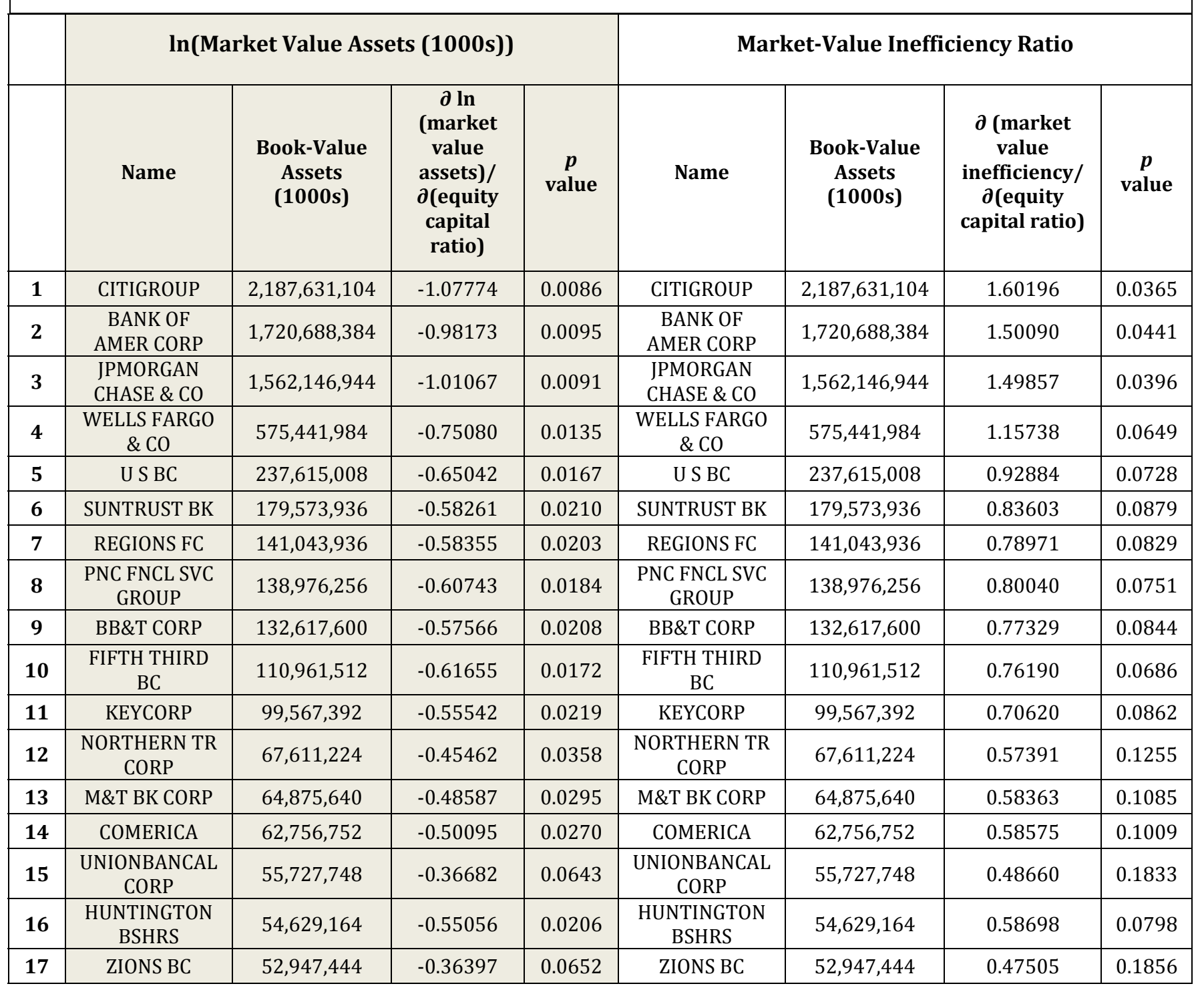




\section{Table 9, continued}

The derivatives of the $\ln$ (market value of assets) are ordered by their statistical significance for all values significant at least at 10 percent.

\section{Panel B}

\begin{tabular}{|c|c|c|c|c|}
\hline & \multicolumn{4}{|c|}{ In(Market Value Assets (1000s)) } \\
\hline & Name & $\begin{array}{c}\text { Book-Value } \\
\text { Assets } \\
\text { (1000s) }\end{array}$ & $\begin{array}{c}\boldsymbol{l n} \text { (market } \\
\text { value } \\
\text { assets)/ } \\
\partial \text { (equity } \\
\text { capital } \\
\text { ratio) }\end{array}$ & $p$ value \\
\hline 1 & CITIGROUP & $2,187,631,104$ & -1.07774 & 0.0086 \\
\hline 2 & JPMORGAN CHASE \& CO & $1,562,146,944$ & -1.01067 & 0.0091 \\
\hline 3 & BANK OF AMER CORP & $1,720,688,384$ & -0.98173 & 0.0095 \\
\hline 4 & WELLS FARGO \& CO & $575,441,984$ & -0.75080 & 0.0135 \\
\hline 5 & U S BC & $237,615,008$ & -0.65042 & 0.0167 \\
\hline 6 & FIFTH THIRD BC & $110,961,512$ & -0.61655 & 0.0172 \\
\hline 7 & PNC FNCL SVC GROUP & $138,976,256$ & -0.60743 & 0.0184 \\
\hline 8 & REGIONS FC & $141,043,936$ & -0.58355 & 0.0203 \\
\hline 9 & HUNTINGTON BSHRS & $54,629,164$ & -0.55056 & 0.0206 \\
\hline 10 & BB\&T CORP & $132,617,600$ & -0.57566 & 0.0208 \\
\hline 11 & SUNTRUST BK & $179,573,936$ & -0.58261 & 0.0210 \\
\hline 12 & KEYCORP & $99,567,392$ & -0.55542 & 0.0219 \\
\hline 13 & COMERICA & $62,756,752$ & -0.50095 & 0.0270 \\
\hline 14 & M\&T BK CORP & $64,875,640$ & -0.48587 & 0.0295 \\
\hline 15 & NORTHERN TR CORP & $67,611,224$ & -0.45462 & 0.0358 \\
\hline 16 & FIRST HORIZON NAT CORP & $37,017,240$ & -0.41211 & 0.0430 \\
\hline 17 & NEW YORK CMNTY BC & $30,599,738$ & -0.38809 & 0.0496 \\
\hline 18 & BANK OF HI CORP & $10,472,942$ & -0.36231 & 0.0502 \\
\hline 19 & UNIONBANCAL CORP & $55,727,748$ & -0.36682 & 0.0643 \\
\hline 20 & ZIONS BC & $52,947,444$ & -0.36397 & 0.0652 \\
\hline 21 & ASSOCIATED BANC CORP & $21,592,084$ & -0.33739 & 0.0698 \\
\hline 22 & FIRSTMERIT CORP & $10,407,565$ & -0.31606 & 0.0741 \\
\hline 23 & TCF FC & $16,067,612$ & -0.31430 & 0.0810 \\
\hline 24 & COMMERCE BSHRS & $16,212,371$ & -0.31314 & 0.0820 \\
\hline 25 & WEBSTER FNCL CORP & $17,208,062$ & -0.30487 & 0.0891 \\
\hline 26 & WHITNEY HC & $11,029,846$ & -0.29230 & 0.0928 \\
\hline 27 & CENTRAL PACIFIC FNCL CORP & $5,680,386$ & -0.27814 & 0.0947 \\
\hline 28 & FULTON FNCL CORP & $15,923,098$ & -0.29563 & 0.0956 \\
\hline 29 & FIRST CITIZENS BSHRS & $16,229,958$ & -0.29242 & 0.0987 \\
\hline
\end{tabular}




\section{Table 10}

Comparisons of Financial Performance in 2007 for Banks with Positive and Significantly Negative Derivatives of Financial Performance with Respect to Equity Capital Ratio

The data set includes 142 publicly traded top-tier bank holding companies at the end of 2007 . There are 33 banks with a positive valued derivative of the $\ln$ (market value of assets), but none of these values are statistically significant. Hence, lacking any statistically significant positive values, these 33 banks are used in the comparison of means with the 29 banks whose negative derivative is significantly different from 0 . In the case of the derivative of market-value inefficiency with respect to the capital ratio, there are 61 banks with a statistically significant negative derivative and 13 banks with a statistically significant positive derivative. The $p$ value represents the statistical significance of the comparison of means in the pairing. Pairs of means in bold are statistically different at stricter than $p=0.10$.

\begin{tabular}{|c|c|c|c|c|c|c|}
\hline & \multicolumn{3}{|c|}{$\begin{array}{c}\partial \ln \text { (Market Value of Assets) } / \partial \text { Capital } \\
\text { Ratio }\end{array}$} & \multicolumn{3}{|c|}{ 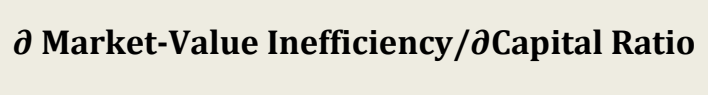 } \\
\hline & $\begin{array}{c}>0 \\
\mathrm{~N}=33\end{array}$ & $\begin{array}{c}<0 \\
\mathrm{~N}=29\end{array}$ & & $\begin{array}{c}<0 \\
\mathrm{~N}=61\end{array}$ & $\begin{array}{c}>0 \\
\mathrm{~N}=13\end{array}$ & \\
\hline & Mean & Mean & $P$ & Mean & Mean & $P$ \\
\hline 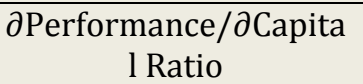 & 0.0756 & -0.5042 & $<0.0001$ & -0.3769 & 0.9637 & $<0.0001$ \\
\hline $\begin{array}{l}\text { Book Value Assets } \\
(1,000 \mathrm{~s})\end{array}$ & $1,815,671$ & $263,905,273$ & 0.0172 & $2,154,360$ & $554,126,921$ & 0.0207 \\
\hline $\begin{array}{c}\text { Investment } \\
\text { Opportunity Ratio }\end{array}$ & 1.1295 & 1.0852 & $<0.0001$ & 1.1128 & 1.0813 & 0.0015 \\
\hline Tobin's $q$ Ratio & 1.0645 & 1.0749 & 0.3599 & 1.0626 & 1.0703 & 0.4943 \\
\hline $\begin{array}{l}\text { Noise-Adjusted Tobin's } \\
\qquad \text { Ratio }\end{array}$ & 1.0490 & 1.0779 & 0.0051 & 1.0530 & 1.0715 & 0.0592 \\
\hline $\begin{array}{l}\text { Market-Value } \\
\text { Inefficiency Ratio }\end{array}$ & 0.4968 & 0.1036 & $<0.0001$ & 0.4577 & 0.0631 & $<0.0001$ \\
\hline $\begin{array}{l}\text { Book-Value Equity/ } \\
\text { Total Assets }\end{array}$ & 0.0915 & 0.0923 & 0.8665 & 0.0917 & 0.0909 & 0.8866 \\
\hline $\begin{array}{c}\text { (Equity + Sub Debt + } \\
\text { Loan Loss Reserves)/ } \\
\text { Assets }\end{array}$ & 0.1010 & 0.1204 & 0.0004 & 0.1008 & 0.1260 & $<0.0001$ \\
\hline $\begin{array}{l}\text { Nonperforming } \\
\text { Loans/Assets }\end{array}$ & 0.0191 & 0.0173 & 0.6544 & 0.0176 & 0.0215 & 0.2162 \\
\hline
\end{tabular}


Table 11

Comparisons of Balance Sheets for Banks in 2007 with Positive and Significantly Negative Derivatives of Financial Performance with Respect to Equity Capital Ratio

The data set includes 142 publicly traded top-tier bank holding companies at the end of 2007. There are 33 banks with a positive valued derivative of the $\ln$ (market value of assets), but none of these values are statistically significant. Hence, lacking any statistically significant positive values, these 33 banks are used in the comparison of means with the 29 banks whose negative derivative is significantly different from 0 . In the case of the derivative of market-value inefficiency with respect to the capital ratio, there are 61 banks with a statistically significant negative derivative and 13 banks with a statistically significant positive derivative. The $p$ value represents the statistical significance of the comparison of means in the pairing. Pairs of means in bold are statistically different at stricter than $p=0.10$.

\begin{tabular}{|c|c|c|c|c|c|c|}
\hline & \multicolumn{3}{|c|}{$\begin{array}{c}\partial \ln (\text { Market Value of Assets) } / \partial \text { Capital } \\
\text { Ratio }\end{array}$} & \multicolumn{3}{|c|}{$\partial$ Market-Value Inefficiency/ $\partial$ Capital Ratio } \\
\hline & $\begin{array}{c}>0 \\
\mathrm{~N}=33\end{array}$ & $\begin{array}{c}<0 \\
\mathrm{~N}=29\end{array}$ & & $\begin{array}{c}<0 \\
\mathrm{~N}=61\end{array}$ & $\begin{array}{c}>0 \\
\mathrm{~N}=13\end{array}$ & \\
\hline & Mean & Mean & $P$ & Mean & Mean & $P$ \\
\hline $\begin{array}{c}\text { Book Value Assets } \\
(1,000 \mathrm{~s})\end{array}$ & $1,815,671$ & $263,905,273$ & 0.0172 & $2,154,360$ & $554,126,921$ & 0.0207 \\
\hline $\begin{array}{c}\text { Deposits/ } \\
\text { (Deposits + Other } \\
\text { Borrowed Funds) }\end{array}$ & 0.8678 & 0.6833 & $<0.0001$ & 0.8649 & 0.6341 & 0.0010 \\
\hline $\begin{array}{l}\text { Noninterest Income/ } \\
\text { Total Revenue }\end{array}$ & 0.1275 & 0.2496 & $<0.0001$ & 0.1468 & 0.2776 & $<0.0001$ \\
\hline Liquid Assets/ Assets & 0.2029 & 0.2065 & 0.8840 & 0.2128 & 0.1794 & 0.2132 \\
\hline $\begin{array}{l}\text { Total Loans/Total } \\
\text { Assets }\end{array}$ & 0.7410 & 0.6670 & 0.0121 & 0.7244 & 0.6427 & 0.0741 \\
\hline $\begin{array}{l}\text { Residential Real Estate } \\
\text { Loans/Total Assets }\end{array}$ & 0.1951 & 0.2510 & 0.0465 & 0.2170 & 0.2180 & 0.9720 \\
\hline $\begin{array}{c}\text { Commercial Real } \\
\text { Estate Loans/Total } \\
\text { Assets }\end{array}$ & 0.3694 & 0.1617 & $<0.0001$ & 0.3256 & 0.1243 & $<0.0001$ \\
\hline $\begin{array}{l}\text { Consumer Loans/Total } \\
\text { Assets }\end{array}$ & 0.0383 & 0.0618 & 0.0444 & 0.0419 & 0.0816 & 0.0022 \\
\hline $\begin{array}{c}\text { Business Loans/Total } \\
\text { Assets }\end{array}$ & 0.1226 & 0.1432 & 0.2703 & 0.1168 & 0.1531 & 0.0951 \\
\hline
\end{tabular}

